\title{
PENGARUH BELANJA PEMERINTAH PUSAT UNTUK FUNGSI LINGKUNGAN HIDUP TERHADAP PERTUMBUHAN EKONOMI INDONESIA
}

\author{
Wawan Hermawan \\ Fakultas Ekonomi dan Bisnis Universitas Padjadjaran \\ Email: w.hermawan@unpad.ac.id
}

\begin{abstract}
Economic development is measured by economic growth. Improving the economy can improve the quality of life in society, so a lot of effort from the government to stimulate the economy to grow better. The positive growth of economy has an impact on the environmental quality of life such as degradation of quality of air, water and land. The government allocates some funds to maintain the quality of the environment by the central budget allocation for environmental functions. The purpose of this study is to measure the impact of the budget allocation for the function of the environment to economic growth. The model used to achieve the purpose of the study is the regression of total government spending to economic growth. To bridge from the expenditure function of the environment against government spending and economic growth model is used Growth Accounting Model. Results of regression calculations and simulations using Growth Accounting, shows expenditures for environmental function has the effect to increase the economic growth of $0.01 \%$ if no additional growth in the rest of expenditures for environmental functions by $10 \%$ ceteris paribus.
\end{abstract}

Keywords: Government spending on Functions of the Environment, Economic Growth

\section{PENDAHULUAN}

embangunan ekonomi di suatu negara bertujuan untuk<smiles>CC1COC1</smiles>
meningkatkan kualitas hidup masyarakat. Peningkatan kualitas hidup ini akan sejalan dengan pertumbuhan ekonomi, dimana terjadi peningkatan atas produksi barang dan jasa yang memberikan efek tersedianya kebutuhan manusia dan naiknya pendapatan sebagai balas jasa faktor produksi di sisi lainnya. Peningkatan barang dan jasa ini tercermin dari peningkatan Produk Domesti Bruto (PDB) sebagai representasi dari kemampuan perekonomian suatu wilayah. Pertumbuhan ekonomi yang tinggi dan berkesinambungan merupakan peningkatan PDB serta memberikan dampak terhadap peningkatan kesejahteraan masyarakat.

QE Journal | Vol.06 - No. 01 Maret 2017 - 1 


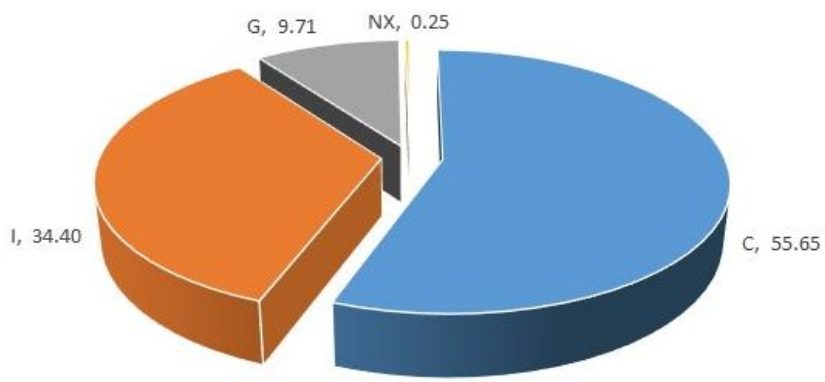

Sumber: Badan Pusat Statistik, diolah

Gambar 1. Proporsi Komponen PDB Nominal Indonesia Tahun 2015

Peran pengeluaran pemerintah dalam mendorong perekonomian menjadi penting. Pemerintah dengan kebijakan fiskalnya dapat mendorong pertumbuhan ekonomi menjadi lebih tinggi, sehingga menarik perhatian para pembuat kebijakan dan juga para akademisi (Gubta et al, 2004). Sudah menjadi lumrah di banyak literatur, bahwa peningkatan pengeluaran pemerintah dapat menjadi alat yang efektif dalam meningkatkan permintaan agregat.

Menurut pandangan Keynesian, pemerintah bisa membalikkan kemerosotan ekonomi dengan meminjam uang dari sektor swasta dan kemudian mengembalikan uang ke sektor swasta melalui berbagai program belanja. Tingginya tingkat konsumsi pemerintah cenderung meningkatkan lapangan kerja, profitabilitas dan investasi melalui efek multiplier pada permintaan agregat. Dengan demikian, pengeluaran pemerintah dapat memberikan kontribusi positif bagi pertumbuhan ekonomi.

Perhatian terhadap masalah lingkungan hidup mulai meningkat dan menjadi isu global ketika konferensi PBB mengenai lingkungan hidup pertama diadakan pada tanggal 5 Juni 1972 di Stockholm, Swedia. Pada pertemuan tersebut, negara-negara sepakat memperbaiki lingkungan dan menyelamatkan bumi. Terakhir konferensi isu dasar yang sama, dilaksanakan di Rio Jainero, pada tanggal 12- 4 Juni 1992, dengan nama KTT Bumi. Dalam pertemuan tersebut - dengan disepakatinya empat dokumen penting yakni Agenda 21, prinsip-prinsip kehutanan, konvensi perubahan iklim dan konvensi keanekaragaman hayati - diletakkan dasar bagi kebijaksanaan pembangunan yang berwawasan lingkungan dan ditinggalkannya eksploitasi sumber bumi secara sewenang-wenang.

QE Journal | Vol.06 - No. 01 Maret 2017 - 2 
Sejak itu himbauan untuk menerapkan konsep pembangunan yang berwawasan lingkungan atau biasa disebut Sustainable Development (pembangunan yang berkelanjutan) makin bergema. Konsep pembangunan yang memiliki arti sebagai "pembangunan yang tidak menurunkan kapasitas generasi yang akan datang untuk melakukan pembangunan". Meskipun terdapat penyusutan sumber daya alam dan lingkungan, tetapi penyusutan tersebut dapat digantikan fungsinya oleh sumber daya manusia maupun sumberdaya kapital. Prasyarat dari konsep pembangunan ini adalah adanya penggunaan sumber daya alam energi yang produktif dan efisien, tanpa memberikan (atau seminimal mungkin) dampak negatif pada manusia dan alam lingkungan.

Seiring dengan gema pembangunan yang berwawasan lingkungan, peran pengeluaran pemerintah sebagai katalisator ekonomi menjadi demikian penting. Dampak langsung dari pengeluaran pemerintah memberikan efek negatif atas emisi $\mathrm{SO}_{2}$ per kapita sedangkan untuk $\mathrm{CO}_{2}$ tidak berpengaruh (Halkos \& Paizanos, 2013). Halkos \& Paizanos juga menjelaskan implikasi atas kebijakan pengeluarannya. Pada negara dengan pendapatan per kapita di bawah US\$10,000, pengurangan pengeluaran pemeritah akan membawa kemunduran kualitas lingkungan sedangkan kondisi terbalik bagi negara dengan pendapatan per kapita yang tinggi.

Peningkatan pengeluaran pemerintah untuk Indonesia, untuk itu perlu ditingkatkan dengan penekanan alokasi khusus untuk penanggulangan krisis lingkungan. Realokasi komposisi belanja pemerintah terhadap barang publik untuk mengurangi polusi sekaligus meningkatkan total pengeluaran pemerintah memiliki dua efek pada polusi (Lopez et al, 2011). Belanja pemerintah pusat sebagai pemegang kekuasaan anggaran yang besar dapat mendorong polusi meningkat atau menurun. Peningkatan belanja berdasarkan fungsi lingkungan hidup diharapkan dapat menurunkan tingkat pencemaran lingkungan.

Pengeluaran untuk belanja berdasarkan fungsi pemerintah pusat lebih banyak untuk fungsi pelayanan umum yang mencapai lebih dari $66 \%$ dari total anggaran (Data Pokok APBN). Pengeluaran untuk fungsi lingkungan hidup hanya $0,9 \%$ dari anggaran yang dikucurkan. Pengeluaran yang rendah untuk lingkungan menjadi hipotesis, apakah jika dinaikan akan ikut meningkatkan kualitas lingkungan atau hanya menjadi beban anggaran yang dapat mengurangi kinerja perekonomian.

QE Journal | Vol.06 - No. 01 Maret 2017 - 3 
Tujuan dari tulisan ini adalah mencari seberapa besar pengaruh dari belanja yang dilakukan oleh pemerintah pusat untuk fungsi lingkugan hidup terhadap pertumbuhan ekonomi. Asumsi seperti yang dikemukakan oleh Gubta et al (2004); Halkos \& Paizanos (2013) dan Lopez et al, (2011) peningkatan pengeluaran pemerintah untuk lingkungan hidup dapat meningkatkan kualitas lingkungan hidup, tetapi sebesar apa dia dapat meningkatkan kinerja pertumbuhan ekonomi.

Penelitian untuk melihat dampak dari pengeluaran pemerintah untuk lingkungan hidup terhadap perekonomian belum banyak dilakukan. Hal ini karena efek yang timbul dari pengeluaran pemerintah untuk lingkungan hidup lebih banyak untuk menjaga atau memperbaiki kualitas lingkungan hidup.

Dampak terhadap pertumbuhan ekonomi mungkin perlu waktu lama untuk dapat dirasakan. Untuk itu Halkos (2013) melakukan penelitian atas dampak langsung dan dampak tidak langsung dari pengeluaran pemerintah ini terhadap lingkungan hidup. Estimasi dari efek langsung pengeluaran pemerintah adalah negatif dan signifikan terhadap $\mathrm{SO}_{2}$ tetapi tidak signifikan terhadap $\mathrm{CO}_{2}$. Walaupun dampak negatif terhadap $\mathrm{SO}_{2}$ ini sesuai dengan temuan Lopez et al. (2011) serta Lopez dan Palacios (2010). Peran jumlah dari pengeluaran pemerintah berdampak negatif terhadap lingkungan pada saat pendapatan nasional rendah dan menjadi positif pada saat tingkat pendapatan nasional tinggi.

Beberapa dekade yang lalu, masalah kualitas lingkungan mendapat perhatian masyarakat sebagai sesuatu yang berhubungan secara khas dengan perkembangan ekonomi industri. Pembangunan sektor industri berhubungan erat dengan pencemaran air dan udara, terutama bahan kimia. Negara-negara yang sedang berkembang, pada awalnya diperkirakan memiliki sedikit masalah lingkungan karena teknologi praindustri dianggap lebih ramah lingkungan dan mereka pun belum terkontaminasi dengan gaya hidup materialistik yang memiliki dampak yang kurang baik.

Pemikiran tersebut ternyata tidak bisa dipertahankan. Pada kenyatannya bahwa kerusakan lingkungan terbesar terjadi di negara-negara berkembang. Daerah-daerah pedesaan memiliki masalah dengan erosi tanah dan memburuknya kualitas air dalam skala yang besar, 
pengundulan hutan (deforestation) dan penurunan produktivitas tanah. Kawasan tersebut telah mengalami penurunan kualitas udara dan air yang cukup serius. Meskipun demikian, kemerosotan lingkungan di negara berkembang bukan masalah keindahan atau kualitas hidup belaka, tetapi isu yang lebih serius lagi yaitu penurunan produktivitas ekonomi dan akselerasi dislokasi sosial. Masalah lingkungan di negara berkembang terlihat lebih kepada masalah hidup dan mati dari pada yang terjadi di negara-negara maju.

Pengeluaran pemerintah untuk menjaga lingkungan tetap diperlukan untuk menjaga pembangunan ekonomi yang berkelanjutan. Tujuan Pembangunan Berkelanjutan atau dalam bahasa Inggris dikenal sebagai Sustainable Development Goals (SDGs) adalah 17 tujuan dengan 169 capaian yang terukur dan tenggat yang telah ditentukan oleh Perserikatan Bangsa Bangsa (PBB) sebagai agenda dunia pembangunan untuk kemaslahatan manusia dan planet bumi. Disepakati saat pertemuan dunia September 2015, Agenda 2030 untuk Pembangunan Berkelanjutan (the 2030 Agenda for Sustainable Development (SDGs)) adalah kesepakatan pembangunan baru yang mendorong perubahan-perubahan yang bergeser ke arah pembangunan berkelanjutan yang berdasarkan hak asasi manusia dan kesetaraan untuk mendorong pembangunan sosial, ekonomi dan lingkungan hidup. SDGs diberlakukan dengan prinsip-prinsip universalitas, integrasi dan inklusif untuk meyakinkan bahwa tidak ada seorang pun yang terlewatkan atau "No one is Left Behind." SDGs terdiri dari 17 Tujuan dan 169 target dalam rangka membangun dari upaya MDGs yang berakhir akhir tahun 2015 (http://www.sdgsindonesia.or.id/).

\section{METODE PENELITIAN}

Model regresi dengan variabel PDB sebagai variabel dependen dijelaskan oleh variabel Belanja Pemerintah Pusat sebagai variabel independen. Variabel Belanja Total yang berisi berdasarkan fungsi pelayanan umum dan fungsi lainnya dikembangkan dari hasil penelitian Rahayu (2004) dan Sodik (2007) sebagai pendekatan dari variabel konsumsi/belanja pemerintah.

$$
\operatorname{Ln}(P D B)_{t}=\beta_{0}+\beta_{1} \operatorname{Ln}(\text { Belanja })_{t}+e_{t}
$$

dimana:

QE Journal | Vol.06 - No. 01 Maret 2017 - 5 
$\beta_{0}=$ Intercept

$\beta_{1}=$ Konstanta variabel bebas

$\varepsilon=$ Error term/derajat kesalahan model

Ln PDB = Logaritma Natural Produk Domestik Bruto Riil

Ln Belanja = Logaritma Natural Belanja Negara

$\mathrm{t}$ = Tahun penelitian, yaitu dari tahun 2000 sampai dengan tahun 2015

Model yang kedua adalah penggunaan Growth Accounting (Solow, 1957). Model ini memberikan sebuah perhitungan atas tingkat pertumbuhan ekonomi (dY/Y) yang disumbangkan oleh pertumbuhan dari tiap komponen ekonomi (di/i) dengan kontribusi dari tiap komponen ekonomi (i/Y) terhadap pertumbuhan ekonominya. Model ini digunakan untuk melakukan simulasi atas pengaruh dari tiap fungsi belanja terhadap pertumbuhan ekonomi melalui koefisien regresi yang sudah dilakukan sebelumnya. Persamaan 2 menunjukkan bahwa pertumbuhan pengeluaran belanja pemerintah $(B)$ merupakan penjumlahan dari perkalian rasio setiap belanja fungsi (i) terhadap total belanja pemerintah dengan pertumbuhan belanja setiap fungsinya.

$$
\frac{d B}{B}=\sum \frac{i}{B} \frac{d i}{i}
$$

Data untuk penelitian ini didapat dari Data Pokok Nota APBN berbagai terbitan. Pengeluaran pemerintah pusat dan pengeluaran transfer menjadi bagian besar dari belanja APBN atau disebut juga dengan belanja negara. Pengeluaran pemerintah pusat ini dapat dibagi menjadi 11 fungsi, dimana salah satunya adalah belanja untuk fungsi lingkungan hidup. Data PDB diambil berdasarkan PDB riil dari Badan Pusat Statistik (BPS).

Untuk mendapatkan hasil regresi yang dapat dipercaya, maka pengujian hasil regresi memerlukan beberapa uji dasar seperti autokorelasi dan uji Heteroskedastisitas (Gujarati, 2003). Uji t dan uji F digunakan untuk analisis model dengan penggunaan tingkat signifikan maksimum $10 \%$ kesalahan.

\section{HASIL DAN PEMBAHASAN}

Perekonomian Indonesia ada pada kisaran 5\% pertumbuhannya per tahun dari tahun 2000 sampai dengan tahun 2015. Dari 2001 sampai dengan 2007, pertumbuhan ada pada tren yang naik, sedangkan dari tahun 2010 sampai

QE Journal | Vol.06 - No. 01 Maret 2017 - 6 
dengan tahun 2015 ada tren yang menurun. Perekonomian Indonesia sempat menurun dari tahun 2008-2009, dimana Indonesia terkena dampak dari krisis keuangan global yang berpusat di Amerika (Sugema, 2012). Gambar 2 berikut menunjukkan bagaimana pola perekonomian Indonesia yang menanjak setelah krisis besar tahun 1998, tapi masih rentan oleh krisis dari luar, walaupun masih tetap tumbuh 4,63\% pada tahun 2009.

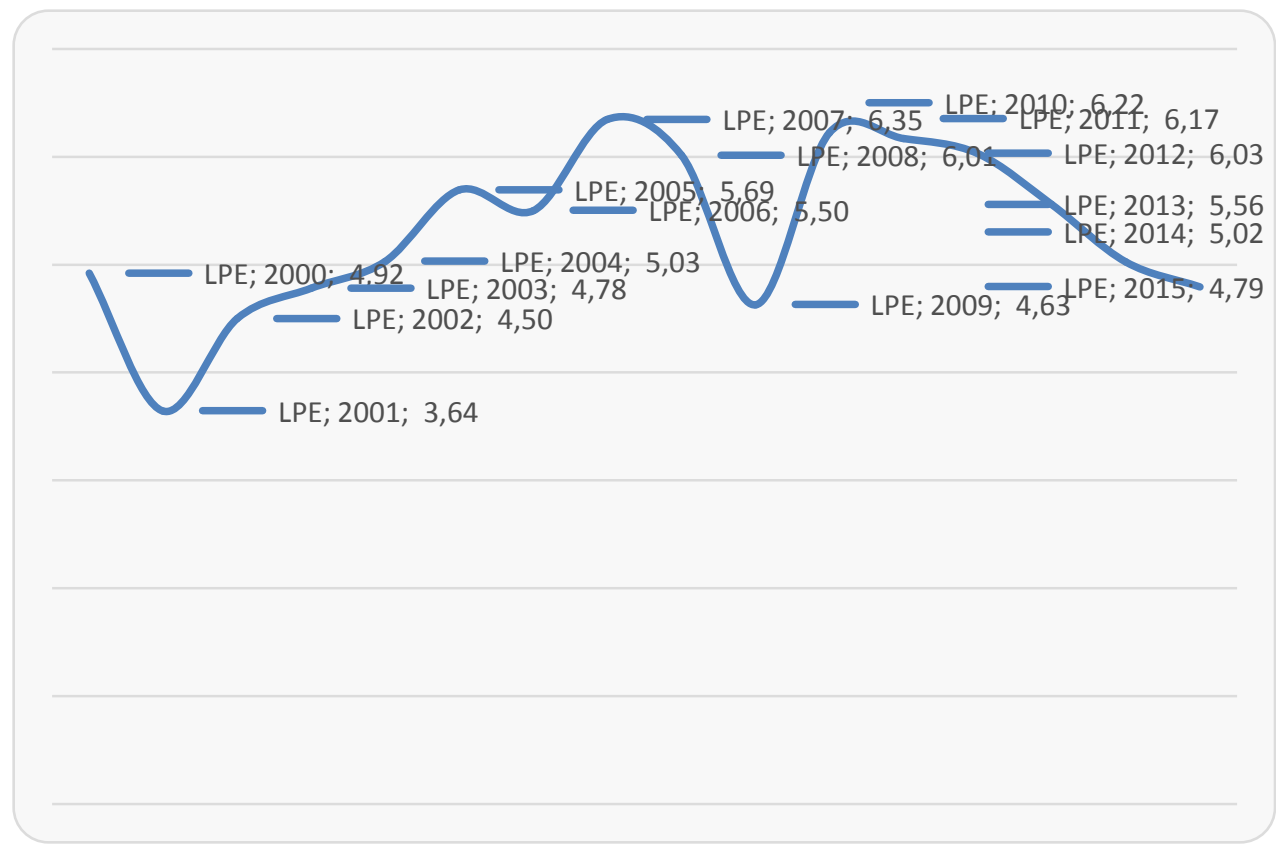

Sumber: Badan Pusat Statistik, diolah

Gambar 2. Pertumbuhan Ekonomi Indonesia (\%)

Peran belanja Pemerintah Indonesia dalam perekonomian ditunjukkan dalam Anggaran Pendapatan dan Belanja Negara (APBN). Perekonomian bisa tumbuh lebih baik dari alamiahnya bila didorong oleh pengeluaran pemerintah, melalui belanja pemerintah. Penelitian dari Ebong et al (2016), Wahyuni et al (2014) dan Miron (2010) telah menunjukkan pentingnya peran pengeluaran pemerintah dalam menstimulus pertumbuhan ekonomi.

Gambar 3 berikut menunjukkan naiknya pegeluaran pemerintah, belanja pusat berdasarkan fungsi dari tahun 2005 sampai dengan tahun 2015. Pertumbuhan selama tahun data ada di sekitar $14,76 \%$, walaupun ada fluktuasi yang cukup tajam pada tahun 2008 dan 2009. Fenomena ini 
diperkirakan sebagai dampak dari resesi pada tahun 2008, dimana terjadi pertumbuhan belanja pusat tahun 2008 berdasarkan fungsi lebih dari dua kalinya dari pertumbuhan pada tahun 2007. Tahun 2009 belanja pusat berdasarkan fungsi ini turun dibandingkan tahun 2008.

Kenaikan dari belanja pusat ini akan menaikan pengeluaran APBN pada tahun berjalan. Proposi yang besar untuk belanja pusat (berdasarkan fungsi) ini ada pada kisaran $68 \%$ selain untuk dana transfer ke daerah dan lainnya yang relatif sangat kecil proporsinya. Untuk itu, kenaikan dari belanja pusat akan menaikan APBN dan kenaikan dari APBN ini akan mempengaruhi pertumbuhan ekonomi pada tahun berjalan. Model untuk melihat perilaku dari pengaruh APBN terhadap pertumbuhan ekonomi dilakukan dengan menerapkan model regresi seperti pada persamaan 1 .

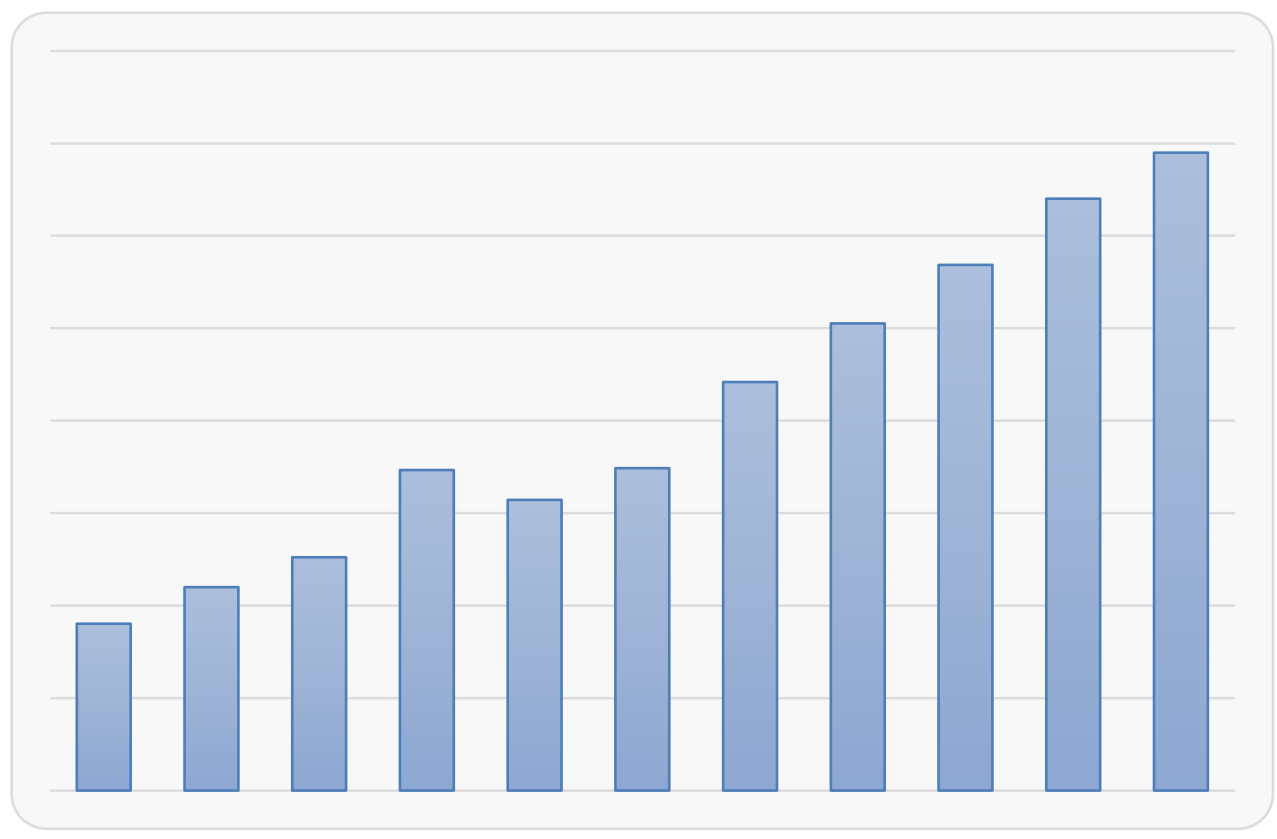

Sumber: Data Pokok APBN Indonesia, diolah

Gambar 3. Belanja Pusat Berdasarkan Fungsi (Trilyun Rupiah)

Regresi yang dilakukan untuk data dari tahun 2000 sampai dengan tahun 2015 memberikan hasil seperti pada persamaan berikut:

$$
\begin{gathered}
\ln \mathrm{PDB}=9,57+0,37 \text { ln Belanja } \\
(51,46)^{* * *} \quad(26,66)^{* * *} \\
\mathrm{R}^{2}=0,98
\end{gathered}
$$


Keterangan: Tanda kurung adalah t-statistik dan ${ }^{* * *}$ (signifikan pada $\alpha=1 \%$ ) Persamaan di atas lolos dalam uji autokorelasi dengan LM Test dan White Heteroskedasticity. Uji T $(26,66)$ dan uji F $(710,87)$ untuk variabel independen dapat disimpulkan model bisa digunakan, demikian pula dengan koefisien determinasi yang memberikan $98 \%$ variasi data variabel dependen dapat dijelaskan oleh variasi di data variabel independennya.

Variabel Belanja Negara signifikan mempengaruhi PDB dalam bentuk logaritma natural. Hasil ini signifikan dalam taraf $\alpha=1 \%$. Kenaikan Belanja pusat sebesar $1 \%$ akan mempengaruhi dalam peningkatan PDB sebesar 0,37\%. Pada hasil ini pertumbuhan ekonomi dipengaruhi oleh pengeluaran belanja daerah sebesar koefisiennya, sehingga mencerminkan peran belanja pemerintah yang positif atas peningkatan pertumbuhan ekonomi di Indonesia. Peran dari belanja negara ini terdiri dari belanja pusat dan transfer ke daerah dengan komposisi rata-rata sebesar $68 \%$ dan $32 \%$. Peran dari pengeluaran berdasarkan fungsi memiliki peran yang lebih besar dibandingkan dengan pengeluaran untuk transfer daerah terhadap pertumbuhan ekonomi. Hal ini jika dilihat dari persentasenya saja.

Pengeluaran pemerintah pusat yang dibagi ke dalam 11 fungsi menunjukkan kontribusi yang beragam terhadap total belanja pusat. Belanja berdasarkan fungsi pelayanan umum merupakan bagian dominan dari semua fungsi yang ada, atau mencakup rata-rata $66 \%$ dari semua belanja pusat pada tahun 2005-2015. Belanja untuk fungi lingkungan hidup masih rendah atau hanya $1 \%$ bahkan lebih rendah dari $1 \%$ pada kenyataannya. Tabel 1 menunjukkan pertumbuhan anggaran belanja pusat berdasarkan fungsi, kontribusi terhadap total belanja pusat dan kontribusi dari pertumbuhan pengeluaran pemerintah pusat di luar transfer ke daerah. Peran dari belanja untuk fungsi lingkungan hidup hanya 0,29\% terhadap pertumbuhan rata-rata pengeluaran pemerintah pusat.

Tahun 2015 merupakan data terakhir yang didapatkan dan dianggap sebagai data dasar untuk dijadikan acuan dalam melakukan simulasi (baseline). Pertumbuhan ekonomi tahun 2015 tercatat sebesar 4,79\%. Berdasarkan model regresi, maka pertumbuhan ini disumbang oleh komponen pengeluaran pemerintah sebesar $1,75 \%$ dan sisanya oleh komponen pengeluaran lain, seperti pengeluaran konsumsi rumah tangga, investasi swasata dan ekspor neto. Hal ini mencerminkan tingginya peran 
pemerintah dalam mendorong perekonomian. Berbagai projek yang dilakukan pemerintah baik dari sisi infrastruktur ataupun dalam bentuk pelayanan, memberikan stimulus kepada masyarakat untuk meningkatkan aktivitas ekonominya.

Tabel 1. Kontribusi dan Pertumbuhan tiap Fungsi Pengeluaran Pemerintah

\begin{tabular}{lccc}
\hline \multicolumn{1}{c}{ Fungsi } & $\begin{array}{c}\text { Rata-rata } \\
\text { Pertumbuhan } \\
\text { 2005-2015 (\%) }\end{array}$ & $\begin{array}{c}\text { Rata-rata } \\
\text { kontribusi 2005- }\end{array}$ & $\begin{array}{c}\text { Kontribusi } \\
\text { Pertumbuhan } \\
\text { Pengeluaran } \\
\text { pemerintah (\%) }\end{array}$ \\
\hline $\begin{array}{l}\text { Pelayanan Umum } \\
\text { Pertahanan }\end{array}$ & 13,90 & 0,66 & 9,23 \\
Ketertiban & 15,97 & 0,05 & 0,81 \\
Keamanan & 10,07 & 0,03 & 0,30 \\
Ekonomi & 17,71 & 0,09 & 1,57 \\
Lingkungan Hidup & 22,77 & 0,01 & 0,21 \\
$\begin{array}{l}\text { Perumahan Dan Fasilitas } \\
\text { Umum }\end{array}$ & 16,04 & 0,02 & 0,35 \\
Kesehatan & 13,48 & 0,02 & 0,28 \\
$\begin{array}{l}\text { Pariwisata Dan Budaya } \\
\text { Agama }\end{array}$ & 13,10 & 0,00 & 0,03 \\
$\begin{array}{l}\text { Pendidikan } \\
\text { Perlindungan Sosial }\end{array}$ & 14,66 & 0,00 & 0,04 \\
\hline Rata-rata Pertumbuhan Belanja Pusat 2005-2015 & 0,11 & 1,59 \\
\hline
\end{tabular}

Sumber: Pengolahan Data

Tingginya peran pemerintah juga menjadi pendorong atas tingginya kerusakan lingkungan atau bisa meningkatkan kualitas dari lingkungan. Peran dari belanja untuk fungsi lingkungan hidup, salah satu tujuannya adalah menjaga kualitas lingkungan hidup. Secara hipotesis, semakin besar belanja pemerintah untuk fungsi lingkungan hidup, diharapkan semakin baik kualitas lingkungan hidup di Indonesia. Data untuk fungsi lingkungan hidup yang didapatkan hanya dari tahun 2005 sampai dengan tahun 2015 atau 11 tahun observasi, berbeda dengan data untuk belanja total yang mencapai 16 tahun observasi. Untuk itu model yang digunakan tidak mengacu pada model regresi tetapi menggunakan model deterministik berupa model Growth Accounting (Solow, 1957). 
Berdasarkan model Growth Accounting, pertumbuhan ekonomi pada tahun 2015 harus ditopang oleh pertumbuhan dari pengeluaran pemerintah setidaknya sebesar 13,09\% pada tahun 2015. Berdasarkan data, pertumbuhan rata-rata pertumbuhan pengeluaran pemerintah untuk tahun 2005-2015 sebesar 14,48\% digunakan sebagai baseline. Perubahan dari belanja pemerintah pusat berdasarkan fungsi akan mempengaruhi kontribusi dari pertumbuhan belanja pemerintah secara keseluruhan. Berdasarkan persamaan 1 dan persamaan 2, maka bisa dihitung berapa dampak terhadap pertumbuhan ekonomi.

Skenario dari simulasi yang dilakukan adalah menambah pertumbuhan dari pengeluaran pusat dari masing-masing fungsi secara parsial. Setiap ada tambahan pertumbuhan dari sebuah fungsi pengeluaran akan mempengaruhi pertumbuhan dari pengeluaran pemerintah secara keseluruhan. Pertumbuhan pengeluaran ini pada gilirannya akan mempengaruhi pertumbuhan ekonomi. Jembatan dari pertumbuhan berdasarkan fungsi ke pertumbuhan pengeluaran pemerintah secara keseluruhan dilakukan melalui persamaan 2, sedangkan dari pertumbuhan pengeluaran pemerintah secara keseluruhan ke pertumbuhan ekonomi melalui persamaan 1 .

Tabel 2. Hasil Simulasi Tambahan Pertumbuhan Belanja Pusat Berdasarkan Fungsi

\begin{tabular}{clcc}
\hline No & $\begin{array}{c}\text { Belanja Pusat Berdasarkan } \\
\text { Fungsi }\end{array}$ & $\begin{array}{c}\text { Tambahan } \\
\text { Pertumbuhan dari } \\
\text { Baseline (\%) }\end{array}$ & $\begin{array}{c}\text { Kenaikan kontribusi } \\
\text { terhadap LPE (\%) }\end{array}$ \\
\hline 1 & Pelayanan Umum & 10 & 0,639 \\
2 & Pertahanan & 10 & 0,052 \\
3 & Ketertiban Dan Keamanan & 10 & 0,029 \\
4 & Ekonomi & 10 & 0,092 \\
5 & Lingkungan Hidup & 10 & 0,010 \\
6 & Perumahan Dan Fasilitas & 10 & 0,022 \\
& Umum & 10 & 0,020 \\
7 & Kesehatan & 10 & 0,002 \\
8 & Pariwisata Dan Budaya & 10 & 0,003 \\
9 & Agama & 10 & 0,003 \\
10 & Pendidikan & 10 & 0,006 \\
11 & Perlindungan Sosial & & \\
\hline
\end{tabular}

Sumber: Pengolahan data

QE Journal | Vol.06 - No. 01 Maret 2017 - 11 
Simulasi dilakukan dengan menambah pertumbuhan masing-masing belanja pemerintah pusat berdasarkan fungsi sebesar 10\%. Pertumbuhan ini dilakukan secara parsial, dimana ada penambahan pertumbuhan untuk fungsi Pelayanan Umum sebesar 10\%, maka belanja fungsi yang lain tidak mengalami perubahan. Tabel 2 menyajikan hasil simulasi untuk masingmasing belanja pemerintah pusat berdasarkan fungsi. Kenaikan yang sama dari pertumbuhan tiap fungsi ini bisa menjadi dasar untuk melihat fungsi mana yang mempunyai dampak terbesar terhadap pertumbuhan ekonomi.

Perhitungan dari simulasi dengan shock yang sama menunjukkan dampak terhadap pertumbuhan ekonomi yang bervariasi. Hasil ini mengindikasikan juga bahwa stuktur pengeluaran publik merupakan faktor penting dalam menentukan pengeluaran pusat berdasarkan fungsi yang mana yang dapat mempengaruhi pertumbuhan ekonomi yang lebih tinggi. Hal ini sesuai dengan penelitian yang dilakukan oleh Ebong et al (2016) dimana kekuatan penelitiannya pada struktur pengeluaran publik, dimana pendidikan dan infrastruktur ekonomi merupakan sektor yang banyak mempengaruhi pertumbuhan ekonomi.

Hasil simulasi jelas menunjukkan bahwa pengeluaran untuk fungsi pelayanan umum memberi dampak peningkatan pertumbuhan ekonomi secara mencolok dibandingkan dengan fungsi-fungsi lainnya. Fungsi Lingkungan Hidup yang merupakan topik utama dari penelitian ini mempunyai peran yang relatif kecil atau merupakan terbesar ke tujuh dari 11 belanja berdasarkan fungsi. Tambahan pertumbuhan pengeluaran fungsi lingkungan hidup sebesar $10 \%$ dari baseline hanya mampu mendongkrak pertumbuhan ekonomi sebesar $0,01 \%$ dari pertumbuhan ekonomi bussines as usual. Jika dilihat dari data tahun 2014 dan 2015, pertumbuhan dari pengeluaran untuk fungsi Lingkungan Hidup mempunyai pertumbuhan yang negatif. Hal ini mengindikasikan adanya pengurangan anggaran untuk fungsi lingkungan hidup. Peningkatan anggaran yang signifikan dilihat dari pertumbuhannya untuk fungsi kesehatan.

Dampak yang kecil dari pengeluaran belanja untuk fungsi lingkungan hidup dan adanya kecenderungan nilai anggaran yang turun di Indonesia, memberikan akibat akan turunnya kualitas lingkungan hidup di Indonesia. Hipotesis ini sesuai dengan temuan dari Lopez et al (2011) dan Halkos \& Paizanos (2013). Peningkatan belanja untuk fungsi lingkungan hidup bisa 
sejalan dengan penurunan subsidi energi untuk mengurangi $\mathrm{CO}_{2}$ yang terpapar di udara. Penurunan subsidi ini berdampak pada penurunan hampir semua output untuk tiap sektor dalam ekonomi (Hermawan, 2016), sehingga kontra produktif dengan pertumbuhan ekonomi.

Indonesia termasuk 12 besar ranking terbaik untuk Public Expenditure and Financial Accountability (PEFA) (Wang et al, 2015), dimana sudah termasuk negara dengan transparan anggaran yang baik. Transparansi ini memberikan kita informasi sejauh mana pemerintah Indonesia mengalokasikan anggarna untuk Lingngan Hidupnya, dan hal ini menjadi ciri dari seberapa jauh perhatian pemerintah terhadap lingkugan hidup. Dampak yang kecil terhadap pertumbuhan ekonomi dan adanya kecenderungan penurunan dari anggaran untuk belanja fungsi lingkungan, harusnya tidak menurunkan semangat untuk melakukan pembangunan ekonomi yang berkelanjutan. Keberlanjutan perekonomian tidak akan lepas dari menjaga kualitas lingkungan hidup sebagai penopang semua aktivitas ekonomi. Perhitungan dampak ekonomi akibat dari tidak menjaga kualitas lingkungan adalah dampak rumah kaca, dimana kerugian yang timbul pada tahap awal bisa mencapai $0,5 \%-1 \%$ dari Produk Domestik Bruto dunia per tahun pada pertengahan abad ini dan terus akan naik jika kita tidak membuat sebuah terobosan untuk melakukan antisipasi (Stern, 2006)

\section{SIMPULAN DAN SARAN}

\section{Simpulan}

Pengeluaran pemerintah mempengaruhi pertumbuhan ekonomi secara signifikan. Arah pengaruh yang positif menunjukkan pengeluaran pemerintah yang lebih tinggi dapat meningkatkan pertumbuhan ekonomi sebagai stimulus terhadap peran komponen ekonomi lainnya dalam mendorong pertumbuhan barang dan jasa.

Pengeluaran untuk belanja pusat berdasarkan 11 fungsi merupakan komponen dari pengeluaran pemerintah. Fungsi pelayanan umum mempunyai dampak yang dominan atau sebesar 64\% terhadap pertumbuhan pengeluaran pemerintah, sehingga dampak tidak langsung terhadap pertumbuhan ekonomi mempunyai peran yang dominan juga. Fungsi Lingkungan Hidup mempunyai dampak yang kecil atau hampir

QE Journal | Vol.06 - No. 01 Maret 2017 - 13 
sebesar 0,01\% dari pertumbuhan ekonomi bussines as usual, jika terjadi kenaikan pertumbuhan belanja fungsi Lingkungan Hidup sebesar 10\% ceteris paribus.

\section{Saran}

Peran belanja fungsi Lingkungan Hidup tidak bisa diabaikan dan harus merupakan prioritas yang tinggi bagi pemerintah. Hal ini untuk mendukung pembangunan ekonomi yang berkelanjutan. Keberlanjutan perekonomian tidak akan lepas dari menjaga kualitas lingkungan hidup sebagai penopang semua aktivitas ekonomi.

\section{DAFTAR PUSTAKA}

Data Pokok APBN, Kementerian Keuangan Republik Indonesia, berbagai terbitan.

Ebong, Friday; Ogwumike, Fidelis; Udongwo, Udeme; Ayodele, Olumide (2016), "Impact of Government Expenditure on Economic Growth in Nigeria: A Disaggregated Analysis", Asian Journal of Economics and Empirical Research, 3(1): 113-121.

Gubta, Sanjeev; Clements, Benedict; Inchauste, Gabriela (2004), “Helping Countries Develpe: The Role of Fiscal Policy", IMF, Washington, D.C.

Gujarati, Domador N. (2003), "Basic Econometrics”, 4th ed., Mc Graw Hill co., New York.

Halkos, George and Paizanos, Epameinondas (2013), "The impact of government expenditure on the environment: An empirical investigation", Ecological Economics 91 (2013) 48-56.

Hermawan, Wawan (2016), “Analisis Kebijakan Fiskal dan Implikasinya Kepada perekonomian Indonesia: Analisis Keseimbangan Umum", QE Journal | Vol.05 - No. 02, June 2016 - page 75-88.

Lopez, R., Galinato, G.I., Islam, F., 2011. Fiscal spending and the environment: theory and empirics. Journal of Environmental Economics and Management 62, 180-198. 
Lopez, R.E., Palacios, A., 2010. Have government spending and energy tax policies contributed to make Europe environmentally cleaner? Working Papers 94795. University of Maryland, Maryland

Miron, Jeffrey (2010), “The negative Consequences of Government Expenditure", Mercatus Working Paper No. 10-83, George Mason University, November 2010.

Rahayu, Siti Aisyah Tri. 2004. "Peranan Sektor Publik Lokal dalam Pertumbuhan Ekonomi Regional di Wilayah Surakarta (1987 2000)". Universitas Sebelas Maret Surakarta. Kinerja, Vol. 8, No. 2, Hal $135-150$.

Sodik, Jamzani. 2007. "Pengeluaran Pemerintah dan Pertumbuhan Ekonomi Regional: Studi Kasus Data Panel di Indonesia". UPN Veteran Yogyakarta. Jurnal Ekonomi Pembangunan, Vol. 12, No. 1, Hal $27-36$.

Solow, Robert (1957). "Technical change and the aggregate production function". Review of Economics and Statistics. 39 (3): 312-320. JSTOR 1926047.

Statistik Lingkungan Hidup Indonesia, 2016, Badan Pusat Statistik

Stern, Nicholas (2006), "The Economics of Climate Change: The Stern Review", Cambridge University Press, ISBN-13: 9780521700801

Sugema, Iman (2012), “Krisis Keuangan Global 2008-2009 dan Implikasinya pada Perekonomian Indonesia", Jurnal Ilmu Pertanian Indonesia (JIPI), Desember 2012, Vol. 17 (3): 145-152, ISSN 0853 - 4217

Wahyuni, I Gusti Ayu Putri; Sukarsa, Made; Yuliarmi, Nyoman (2014), "Pengaruh Pengeluaran Pemerintah dan Investasi Terhadap Pertumbuhan Ekonomi dan Kesenjangan Pendapatan Kabupaten/Kota di Provinsi Bali", E-Jurnal Ekonomi dan Bisnis Universitas Udayana 3.8 (2014) :458-477, ISSN : 2337-3067.

Wang ,Rachel F.; Irwin, Timothy C.; Murara, Lewis K (2015), “Trends in Fiscal Transparency: Evidence from a New Database of the Coverage of Fiscal Reporting", IMF Working Paper, WP/15/188.

http://www.sdgsindonesia.or.id/..

QE Journal | Vol.06 - No. 01 Maret 2017 - 15 